\title{
RANCANGAN APLIKASI KALKULATOR ILMU FALAK BERBASIS SMARTPHONE
}

\author{
Abdul Hayat ${ }^{1}$ \\ Esa Rizki Hari Utama ${ }^{2}$ \\ Dosen Jurusan Komputerisasi Akuntansi AMIK Raharja Informatika ${ }^{1}$ \\ Mahasiswa STMIK Raharja Jurusan Teknik Informatika ${ }^{2}$ \\ ${ }^{1}$ AMIK Raharja Informatika - Tangerang \\ ${ }^{2}$ STMIK Raharja - Tangerang \\ ${ }^{1,2}$ Jl. Jendral Sudirman No.40, Modern Cikokol, Tangerang \\ E-mail : abdul.hayat@raharja.ac.id ${ }^{1}$, utama@raharja.info ${ }^{2}$
}

Diterima: 4 Juli 2018/ Disetujui : 21 Juli 2018

\begin{abstract}
In practice, astronomy studies about how to calculate the direction of qibla, the beginning of prayer time, the beginning of the month of Hijri and the possibility of eclipses. Usually people who are studying astronomy do calculations by manual. Performing calculations manually has a risk in terms of calculation accuracy. Therefore, the presence of this application of astronomy calculators is expected to benefit people, especially Moslems who want to know the position of the Qibla for prayer, to estimate the beginning of the Hijri month, the Hijri calendar, and so forth. This article is an idea how to design a mobile smart phone-based astronomy calculator application. The method begins with literature studies from books and articles on astronomy that have been developed by some previous researchers; then the design is used to describe how the application model of the calculator of astronomy according to smart phone format as a mobile application, either Android or iOS. It is expected that with this mobile application can spread as widely as possible for the utilization of astronomy to all people who need, especially when doing the activities of reckoning and sighting of moon.
\end{abstract}

Keywords: Science of Astronomy, Android, Calculator, Reckoning and Sighting of moon

\begin{abstract}
ABSTRAK
Secara praktis, ilmu falak mengkaji tentang bagaimana cara menghitung posisi arah kiblat, waktu sholat, awal bulan Hijriyah dan kemungkinan terjadinya gerhana. Biasanya orang yang sedang belajar ilmu falak melakukan perhitungan dengan cara manual. Perhitungan ilmu falak dengan cara manual mempunyai risiko dalam hal akurasi perhitungan. Oleh karena itu, kehadiran aplikasi kalkulator ilmu falak ini diharapkan dapat memberikan manfaat bagi orang-orang, terutama umat Muslim yang ingin mengetahui posisi kiblat untuk sholat, memperkirakan awal bulan Hijriyah, kalendar Hijriyah, dan lain-lain. Tulisan ini merupakan gagasan bagaimana merancang aplikasi kalkulator ilmu falak berbasis telepon pintar (smart phone). Metode yang digunakan diawali dengan studi pustaka dari buku-buku dan artikel tentang ilmu falak yang telah dikembangkan oleh beberapa peneliti sebelumnya; kemudian perancangan digunakan untuk menggambarkan bagaimana model aplikasi kalkulator ilmu falak tersebut sesuai format smart phone sebagai aplikasi yang bersifat bergerak (mobile), baik yang berbasis Android maupun iOS. Diharapkan dengan adanya aplikasi mobile ini dapat menyebarkan seluas-luasnya pemanfaatan ilmu falak kepada semua orang yang membutuhkan terutama pada saat melakukan kegiatan hisab dan ru'yatul hilal.
\end{abstract}


Kata kunci : Ilmu Falak, Android, Kalkulator, Hisab, Ru'yatul Hilal

\section{PENDAHULUAN}

Ilmu falak merupakan perpaduan antara matematika dan fisika yang secara sederhana bisa kita definisikan sebagai sebuah bidang ilmu pengetahuan eksak yang objeknya berkaitan dengan bumi, bulan, matahari dan benda langit yang lainnya. Umumnya, objek kajian ilmu falak hanya terkait dengan urusan peribadahan tertentu dalam agama Islam seperti perhitungan mengenai arah kiblat, awal waktu sholat, awal bulan Hijriyah dan perhitungan mengenai kapan terjadinya gerhana[1]. Masalah ilmu falak atau dikenal dengan nama lain sebagai falakiyah ini merupakan kebutuhan bagi setiap muslim baik untuk keperluan seharihari, setiap bulan, setiap tahun, maupun sesekali dalam beberapa tahun. Setiap hari seorang muslim memerlukan informasi tentang waktu sholat yang 5 (lima) waktu. Seorang muslim memerlukan informasi tentang arah kiblat terutama pada saat melakukan perjalanan ke luar kota. Setiap bulan umat Islam membutuhkan informasi tentang awal bulan Hijriyah, serta setiap tahun umat Islam memerlukan informasi tentang awal Ramadhan, Idul Fithri, Idul Adha, dan lain-lain.

Secara umum metode perhitungan ilmu falak masih banyak yang menggunakan cara manual. Orang yang hendak melakukan perhitungan biasanya menggunakan lembar kerja yang berisikan rumus yang kemudian lembar kerja tersebut diisi satu persatu dengan menggunakan data yang berasal dari hasil perhitungan rumus yang ada. Perhitungan yang dilakukan dengan cara manual tersebut memungkinkan terjadinya kesalahan dan juga memerlukan waktu yang relatif lama. Hal ini disebabkan karena prosedur yang cukup panjang dan rumus yang digunakan banyak menggunakan rumus trigonometri, meski dengan bantuan kalkulator ilmiah. Dengan demikian sangatlah mungkin akurasinya rendah apabila dilakukan secara manual. Di samping itu juga informasi yang didapat hanya diketahui oleh beberapa orang dari kalangan terbatas, sementara umat Islam yang lainnya yang tidak terlibat dalam perhitungan ilmu falak hanya bisa menunggu pengumuman resmi.

Oleh karena itu, inisiatif pembuatan aplikasi ilmu falak ini akan sangat membantu masyarakat, khususnya umat Islam, kapanpun dan dimanapun mereka berada. Aplikasi ini dapat dimanfaatkan melalui desktop PC, laptop, dan juga smart phone. Dengan demikian informasi tentang ilmu falak dapat diperoleh lebih mudah dengan mengakses aplikasi ilmu falak melalui peralatan yang dimiliki oleh pemakai, baik desktop PC, laptop, maupun smart phone.

Tulisan ini membahas tentang prototype aplikasi kalkulator ilmu falak yang berisi perhitungan arah kiblat, perhitungan waktu shalat dan perhitungan awal bulan Hijriyah. Prototype aplikasi dirancang berdasarkan aplikasi bergerak (mobile) yang diakses melalui smart phone.

\section{IDENTIFIKASI MASALAH}

Berdasarkan apa yang telah diuraikan diatas, maka dapat diidentifikasikan permasalahan yang ada dalam pemanfaatan ilmu falak adalah :

1. Perhitungan ilmu falak dilakukan secara manual menggunakan lembar kerja dengan bantuan kalkulator ilmiah.

2. Perhitungan ilmu falak jika dilakukan secara manual menggunakan lembar kerja akan membutuhkan waktu yang cukup lama dan membutuhkan konsentrasi yang tinggi, serta mempunyai risiko dalam hal akurasi perhitungan.

3. Aplikasi kalkulator ilmu falak yang dapat diakses melalui smart phone masih relatif jarang, karena umumnya aplikasi mengenai ilmu falak yang ada, khususnya dalam 
menentukan awal bulan Hijriyah sebagian besar hanya menyajikan data akhir secara instan tanpa memberikan kesimpulan berdasarkan perhitungan.

4. Belum adanya aplikasi yang dapat dijadikan sebagai rujukan atau referensi hasil perhitungan bagi orang-orang yang mempelajari Ilmu Falak.

\section{LITERATURE REVIEW}

1. Penelitian yang dilakukan oleh Muhammad Nashiruddin Darajat, Abdul Fadlil dan Sunardi mengenai "SISTEM INFORMASI ARAH KIBLAT DAN JADWAL WAKTU SHALAT BERBASIS ANDROID"[2]. Jadwal waktu shalat merupakan sekumpulan jadwal waktu yang menghimpun lima waktu shalat, yaitu Zuhur, Ashar, Mahgrib, Isya', dan Subuh. Jadwal waktu shalat merupakan hal yang terbilang penting bagi orang muslim untuk dipergunakan sebagai pedoman sehari-hari dalam menentukan awal waktu shalat. Jadwal waktu shalat secara sederhana bisa dibuat menjadi sebuah program pada kalkulator atau komputer yang bisa dipergunakan untuk memberi kemudahan terhadap penggunanya. Metode perhitungan awal waktu shalat biasa ditentukan berdasarkan posisi perjalanan matahari yang terlihat pada suatu tempat yang ada di permukaan bumi. Penentuan arah kiblat pada sebuah masjid merupakan pengukuran letak geografis pada sebuah tempat yang mana arah kiblat masjid ditentukan berdasarkan perhitungan arah/azimut kiblat dengan mempergunakan bantuan alat hitung berupa kalkulator atau komputer. Sedangkan untuk metode pengukurannya biasanya menggunakan alat bantu berupa kompas, GPS, atau theodolit. Penentuan arah kiblat masjid merupakan sebuah perkara yang sangat penting bagi umat Islam, karena menghadap arah kiblat dalam shalat merupakan salah satu syarat sahnya shalat. Pada aplikasi pengingat shalat dan arah kiblat atau yang diberi nama AQ-Shalat, peneliti berharap nantinya aplikasi ini bisa membantu umat muslim yang menggunakan handphone dengan sistem operasi android agar bisa melaksanakan shalat tepat waktu dan menghadap kearah kiblat yang semestinya.

2. Penelitian yang dilakukan oleh Moedji Raharto dan Dede Jaenal Arifin Surya mengenai "Telaah Penentuan Arah Kiblat dengan Perhitungan Trigonometri Bola dan Bayang-Bayang Gnomon oleh Matahari" [3]. Pemecahan masalah terkait penentuan sudut arah Kiblat dapat diperoleh melalui informasi koordinat geografis posisi pengamat, posisi Ka'bah dan dengan cara memanfaatkan rumus segitiga bola (spherical trigonometri) yang menjadi penghubung antara parameter yang diketahui dan sudut arah Kiblat yang ingin diketahui. Penentuan beberapa titik posisi yang ada di sekitar Masjid ditentukan dengan menggunakan bantuan alat GPS-map 60CSx. Kemudian hasil informasi mengenai sudut arah Kiblat itu digunakan sebagai masukan dalam menentukan arah Kiblat dengan menggunakan bayang - bayang Gnomon yang tercipta karena adanya cahaya matahari. Alat yang biasanya digunakan pada metode ini adalah Gnomon, Mizwala dan bidang dial. Hal pertama yang kita lakukan yaitu menentukan arah/azimuth bayang - bayang Gnomon pada tanggal dan jam pengamatan di lokasi pengamat, dengan demikian dapat ditentukan arah Utara - Selatan yang sebenarnya, dalam artian bukan arah Utara - Selatan magnit bumi. Setelah itu, kita menetukan arah Kiblat berdasarkan referensi/acuan arah Utara - Selatan yang telah ditentukan sebelumnya. Kegiatan berikutnya adalah penentuan arah dan tinggi bayang - bayang Gnomon di lokasi pengamat saat Matahari berada di atas Ka'bah. Pemeriksaan awal terkait perbandingan hasil penentuan dengan dua cara ini untuk lokasi di sekitar masjid Sabilushalihin, Buah Batu, Bandung tidak terdapat perbedaan nominal yang berarti, jadi kedua metode tersebut mempunyai nilai akurasi yang kurang lebih setara.

3. Penelitian yang dilakukan oleh Suci Novira Aditiani, Dyah Fitriana Masithoh dan Nonoh Siti Aminah mengenai "PENENTUAN ARAH KIBLAT DENGAN METODE SEGITIGA $B O L A$ "'[4].Sudah banyak penelitian yang dilakukan untuk menentukan arah kiblat dengan menggunakan metode perhitungan segitiga bola. Pemahaman mengenai arah kiblat merupakan perkara penting bagi umat islam, karena salah satu syarat sah dalam melaksanakan ibadah shalat adalah menghadap kiblat. Meskipun kini mulai bermunculan teknologi canggih untuk menentukan arah kiblat, namun perlu diketahui bagaimana cara menentukan arah kiblat yang sebenarnya. Perhitungan arah kiblat dengan menggunakan metode perhitungan segitiga 
bola didasari berdasarkan segitiga yang ada pada permukaan bola bumi yang mana segitiga tersebut disusun oleh tiga lingkaran besar bola bumi, yaitu dua lingkaran garis bujur bumi dan satu lingkaran kiblat. Perpotongan yang ada pada ketiga lingkaran besar tersebut meciptakan tiga buah titik, yaitu titik A (Makkah), titik B (lokasi yang akan dihitung arah kiblatnya), dan titik C (Kutub Utara). Proses yang harus dilalui dalam rangka menentukan arah kiblat diantaranya: (1) Mempersiapkan data yang dibutuhkan untuk melakukan perhitungan arah kiblat, yang mana data tersebut biasanya terdiri dari data lintang dan bujur Ka'bah (kota Makkah), serta data mengenai nilai lintang dan bujur tempat/kota yang arah kiblatnya akan dihitung; (2) Penghitungan arah kiblat dengan menggunakan rumus $\cot \mathrm{B}=((\cot \mathrm{b} \times \sin \mathrm{a})$ / $\sin C))+(\cos a x \cot C)$, dengan: $B=$ Sudut arah kiblat suatu tempat, $C=$ Selisih yang ada diantar bujur Ka'bah dengan bujur tempat yang arah kiblatnya akan dicari, a $=90^{\circ}-\varphi$ tp (lintang tempat), dan $b=90^{\circ}-\varphi$ ka (lintang Ka'bah); (3) Penghitungan azimuth kiblat sejati dihitung dari arah utara sejati searah jarum jam, yang mana azimuth kiblat sejati nilainya $=$ $360^{\circ}$ - sudut arah kiblat (B); (4) Penentuan arah kiblat yang sebenarnya dengan cara mengukur menggunakan penggaris busur sebesar azimuth kiblat sejati terhitung dari arah utara sejati.

4. Penelitian yang dilakukan oleh Dede Muhammad Isnaeni, Fitri Mintarsih, Feri Fahrianto mengenai "IMPLEMENTASI ALGORITMA MEEUS DALAM PENENTUAN WAKTU SHALAT DAN PENCARIAN MASJID TERDEKAT"[5]. Di zaman perkembangan teknologi seperti saat ini, peran media komunikasi saat ini sangat penting dalam menjawab setiap kebutuhan, baik kebutuhan jasmani dan rohani. Untuk kebutuhan fisik seperti media sosial dan lain sebagainya, untuk kebutuhan rohani sebagai ceramah agama, digital Qur'an, dan waktu shalat. Untuk dapat menentukan waktu shalat, banyak metode dan pendapat yang berbeda tentang penggunaan algoritma menentukan waktu shalat, salah satunya adalah algoritma Meeus. Jean Meeus adalah seorang astronom dan matematikawan asal belgia yang lahir pada tahun 1928. Ia belajar matematika di Universitas Leuven, Belgia, dan lulus pada tahun 1953. Dia tertarik pada astronomi dan mekanika bola benda langit. Jean Meeus banyak menulis buku yang berhubungan dengan matematika astronomi, seperti Canon gerhana Matahari, Elements Solar gerhana 1951-2200, Canon of Lunar gerhana, Astronomical Formula untuk Kalkulator, Astronomi Algoritma, Transit, Tabel Astronomi dari Matahari, Bulan dan Planet, Matematika Astronomi Morsels. Untuk jasanya di bidang astronomi, sebuah asteriod ditemukan bernama asteroid 2213 Meeus. Algoritma Meeus merupakan algoritma yang banyak digunakan untuk perhitungan astronomi karena diketahui dengan akurasi yang cukup tinggi. algoritma Meeus merupakan sebuah ringkasan algoritma VSOP87 yang memiliki tingkat akurasi yang tinggi, dari ribuan suku VSOP87 koleksi algoritma untuk menentukan posisi matahari, maka yang penting adalah tentang ratusan suku besar dan penting dalam algoritma Meeus ini, sedangkan suku kecil tidak diperhitungkan. Ini tidak mengurangi akurasi dari algoritma perhitungan sendiri Meeus, oleh karena itu penulis menggunakan algoritma Meeus ini dalam menentukan waktu shalat lima waktu. Metode mencari masjid terdekat, penulis menggunakan data base yang bersumber dari Google, hal ini disebabkan keterbatasan waktu, tenaga dan kemampuan untuk kembali penulis untuk merekam masjid untuk dimasukkan dalam penelitian ini.

5. Penelitian yang dilakukan oleh Burhan mengenai "Penetapan Arah Kiblat melalui Media Online : Google Earth dan Qibla Locator"[6]. Telah dilakukan selancar dalam dunia maya melalui internet dan citra satelit. Penetapan arah kiblat melalui media online dilakukan dengan mengunjungi software Google Earth dan Qibla Locator. Hasil penelusuran sangat memudahkan pengguna untuk mengetahui secara cepat dan presisi, hemat waktu, hemat biaya dan hemat energi, untuk menemukan arah kiblat suatu tempat. Arah kiblat suatu tempat melalui dua software ini dapat digunakan untuk kalibrasi arah kiblat masjid di berbagai tempat. Pengukuran lapangan diperlukan untuk melakukan pengecekan akurasi arah kiblat masjid yang sebenarnya. Qibla Locator mempunyai penyajian yang lebih praktis, karena khusus menampilkan arah kiblat, disertai parameter-parameter fisis yang diperlukan dalam penentuan arah kiblat. Parameter fisis tersebut dapat digunakan untuk koreksi perhitungan dengan menggunakan rumus matematika atau rumus segitiga bola. 
Pengukuran dengan menggunakan Google Earth maupun pengukuran dengan menggunakan Qibla Locator, masih harus dilakukan pengukuran lapangan terutama untuk kalibrasi arah kiblat tertentu, seperti arah kiblat masjid dan arah kiblat kuburan. Diperlukan GPS untuk mengetahui posisi suatu tempat yang ingin diketahui arah kiblatnya.

\section{HASIL DAN PEMBAHASAN}

\section{Metode perhitungan yang berjalan}

Dibawah ini adalah contoh lembar kerja yang harus dipersiapkan dan di isi untuk mendapatkan hasil mengenai arah kiblat, awal waktu sholat dan awal bulan hijriyah.

\section{Lembar Kerja Arah Kiblat}

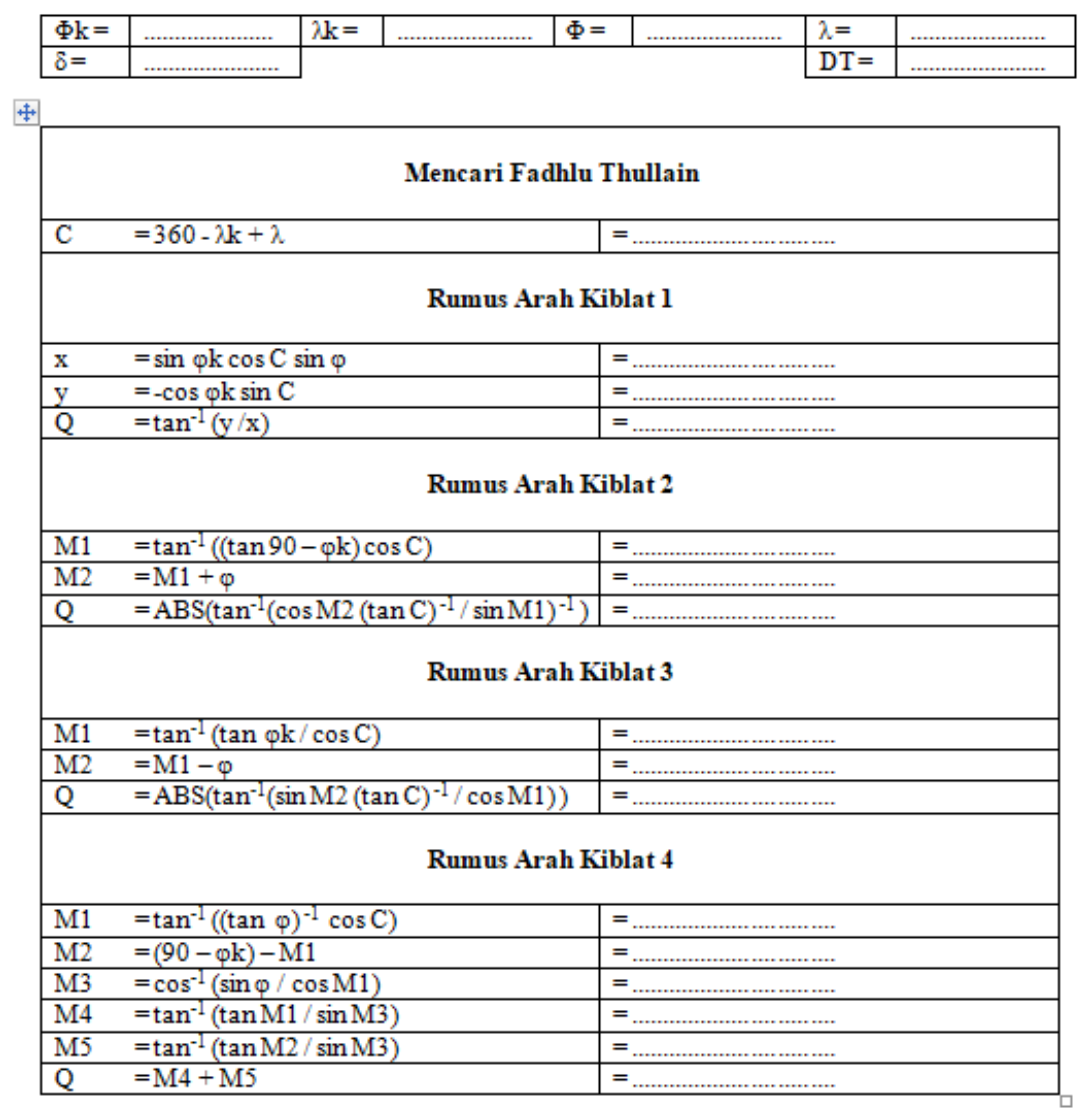

Pada lembar ini siapa saja yang hendak melakukan perhitungan terlebih dahulu harus mencari data geografis dan data astronomis matahari. Data geografis berisikan data lintang ka'bah ( $\Phi \mathrm{k})$, bujur ka'bah $(\lambda \mathrm{k})$ dan data lintang tempat $(\Phi)$ serta bujur tempat $(\lambda)$ yang akan dicari arah kiblatnya. Teruntuk data astronomis matahari yang harus disiapkan adalah data deklinasi matahari $(\delta)$ dan data perata waktu (DT) pada tanggal dimana kita hendak melakukan perhitungan. Selanjutnya mencari fadhlu thullain untuk melengkapi data yang dibutuhkan untuk melakukan perhitungan. Kemudian setelah data tersebut dilengkapi barulah kita bisa melakukan perhitungan arah kiblat menggunakan 4 rumus yang telah disediakan yang mana hasilnya merupakan arah kiblat dihitung dari 4 arah yang berbeda. Kemudian kita mempergunakan hasil perhitungan tersebut pada sebuah kompas untuk mendapatkan hasil sesungguhnya terkait arah kiblat yang telah didapatkan. 


\section{Lembar kerja bayang-bayang kiblat}

\begin{tabular}{|c|c|c|}
\hline \multicolumn{3}{|c|}{ Mencari Bayang - Bayang Kiblat } \\
\hline $\mathrm{AQ}$ & $=$ Arah Kiblat & 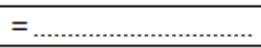 \\
\hline $\mathrm{b}$ & $=90-\varphi$ & 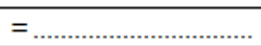 \\
\hline $\mathrm{a}$ & $=90-\mathrm{D}$ & $=\ldots \ldots \ldots \ldots \ldots \ldots \ldots \ldots \ldots \ldots$ \\
\hline $\mathrm{P}$ & $=\tan ^{-1}(\cos C x \tan A Q)^{-1}$ & 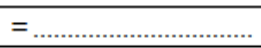 \\
\hline $\mathrm{CP}$ & $=\cos ^{-1}\left((\tan a)^{-1} x \tan b x \cos P\right)$ & 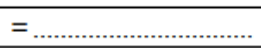 \\
\hline $\mathrm{t} 1$ & $=\mathrm{CP}-\mathrm{P}$ & 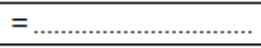 \\
\hline $\mathrm{t} 2$ & $=-\mathrm{CP}-\mathrm{P}$ & $=\ldots \ldots \ldots \ldots \ldots \ldots \ldots \ldots \ldots \ldots$ \\
\hline W1 & $=12-\mathrm{e}+\mathrm{t} 1 / 15+((\mathrm{TZ} \times 15)-\lambda) / 15$ & = \\
\hline W2 & $=12-\mathrm{e}+\mathrm{t} 2 / 15+((\mathrm{TZ} \times 15)-\lambda) / 15$ & 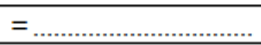 \\
\hline
\end{tabular}

Lembar kerja ini berisikan rumus lebih lanjut terkait perhitungan arah kiblat yang mana rumus ini bertujuan untuk mencari waktu dimana bayang-bayang sebuah benda yang tegak lurus menghadap langsung kearah kiblat. Disini peneliti beranggapan bahwa metode perhitungan yang dilakukan menggunakan lembar kerja kurang efisien karena membutuhkan waktu yang terbilang lama untuk mengerjakannya dan harus menghamburkan kertas. Karena hasil dari perhitungan tersebut nilainya dihitung berdasarkan data geografis pada satu tempat, dan jika ingin mengetahui arah kiblat pada tempat yang lain maka kita harus mengulangi perhitungan arah kiblat tersebut.

\section{Lembar kerja waktu sholat}

WAKTU SHOLAT

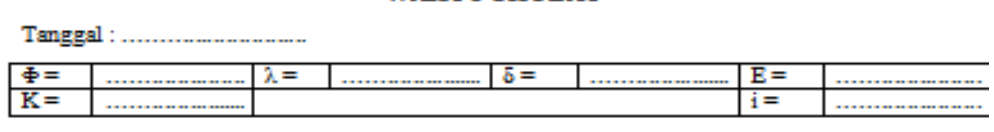

\begin{tabular}{|c|c|}
\hline \multicolumn{2}{|c|}{ AWAL WAKTU ZUHUR (Z) } \\
\hline$Z=12-E+(105-\Phi) / 15+i$ & 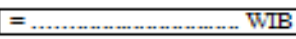 \\
\hline \multicolumn{2}{|c|}{ AWAL WAKTU ASHAR (WA) } \\
\hline $\mathrm{h}=\tan ^{-1}(1 / \tan \mathrm{Abs}(\Phi-5)+1)$ & 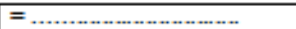 \\
\hline$t=\cos ^{-1}(-\tan \Phi \tan 5+\sinh / \cos \Phi / \cos 5)$ & 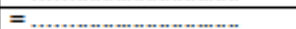 \\
\hline WA $=Z+t / 15$ & 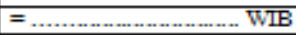 \\
\hline \multicolumn{2}{|c|}{ AWAL WAKTU MAGHRIB (WM) } \\
\hline $\begin{array}{l}\mathrm{h}=- \text { semi diameter }- \text { refraksi - kerendahan } \\
\text { ufug }\end{array}$ & $=\ldots \ldots \ldots+\ldots \ldots+\ldots \ldots \ldots+\ldots$ \\
\hline $\mathrm{t}=\cos ^{-1}(-\tan \Phi \tan 5+\sinh / \cos \Phi / \cos 5)$ & 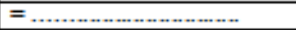 \\
\hline $\mathrm{WM}=\mathrm{Z}+\mathrm{t} / 15$ & 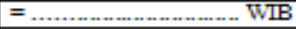 \\
\hline \multicolumn{2}{|c|}{ AWAL WAKTU ISYA' (WI) } \\
\hline \multicolumn{2}{|l|}{$\mathrm{h}=-18$} \\
\hline$t=\cos ^{-1}(-\tan \Phi \tan \delta+\sinh / \cos \Phi / \cos \delta)$ & 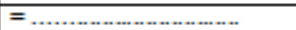 \\
\hline $\mathrm{WI}=\mathrm{Z}+\mathrm{t} / 15$ & $=\ldots \ldots \ldots \ldots \ldots \ldots \ldots \ldots \ldots$ WIB \\
\hline \multicolumn{2}{|c|}{ AWAL WAKTU SUBUH (WS) } \\
\hline \multicolumn{2}{|l|}{$\mathrm{h}=-20$} \\
\hline$t=\cos ^{-1}(-\tan \Phi \tan 5+\sinh / \cos \Phi / \cos 5)$ & $=\ldots \ldots \ldots \ldots \ldots \ldots \ldots \ldots \ldots \ldots \ldots \ldots \ldots$ \\
\hline WS $=Z+t / 15$ & 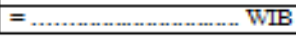 \\
\hline \multicolumn{2}{|c|}{ AKHIR WAKTU SUBUH (TERBIT) (WT) } \\
\hline $\mathrm{t}=$ sama dengan waktu maghrib & $=\ldots \ldots \ldots \ldots \ldots \ldots \ldots \ldots+\ldots \ldots \ldots$ \\
\hline $\mathrm{WT}=\mathrm{Z}-\mathrm{t} / 15-2 \mathrm{xi}$ & 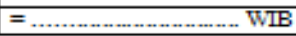 \\
\hline \multicolumn{2}{|c|}{ AWAL WAKTU DHUHA (WD) } \\
\hline $\mathrm{h}=4.5$ & \\
\hline $\mathrm{t}=\cos ^{-1}(-\tan \Phi \tan \delta+\sin \mathrm{h} / \cos \Phi / \cos \delta)$ & 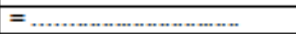 \\
\hline WS $=Z-t / 15$ & 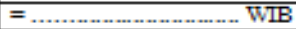 \\
\hline
\end{tabular}


Pada lembaran ini siapa saja yang hendak melakukan perhitungan terkait awal waktu sholat terlebih dahulu mencari data lintang tempat $(\Phi)$, bujur tempat $(\lambda)$, deklinasi matahari $(\delta)$, perata waktu $(E)$, tinggi tempat (K) dan ihtiyat (i). Setelah data tersebut dilengkapi barulah dia bisa melakukan perhitungan terkait awal waktu sholat. Peneliti beranggapan bahwa metode perhitungan yang seperti ini masih dirasa cukup merepotkan, karena satu lembar rumus perhitungan waktu tersebut hasilnya dipergunakan hanya untuk waktu satu hari dan jika ingin menghitung waktu sholat dihari berikutnya maka harus kembali melakukan perhitungan.

\section{Lembar Kerja Awal Bulan Hijriyah}
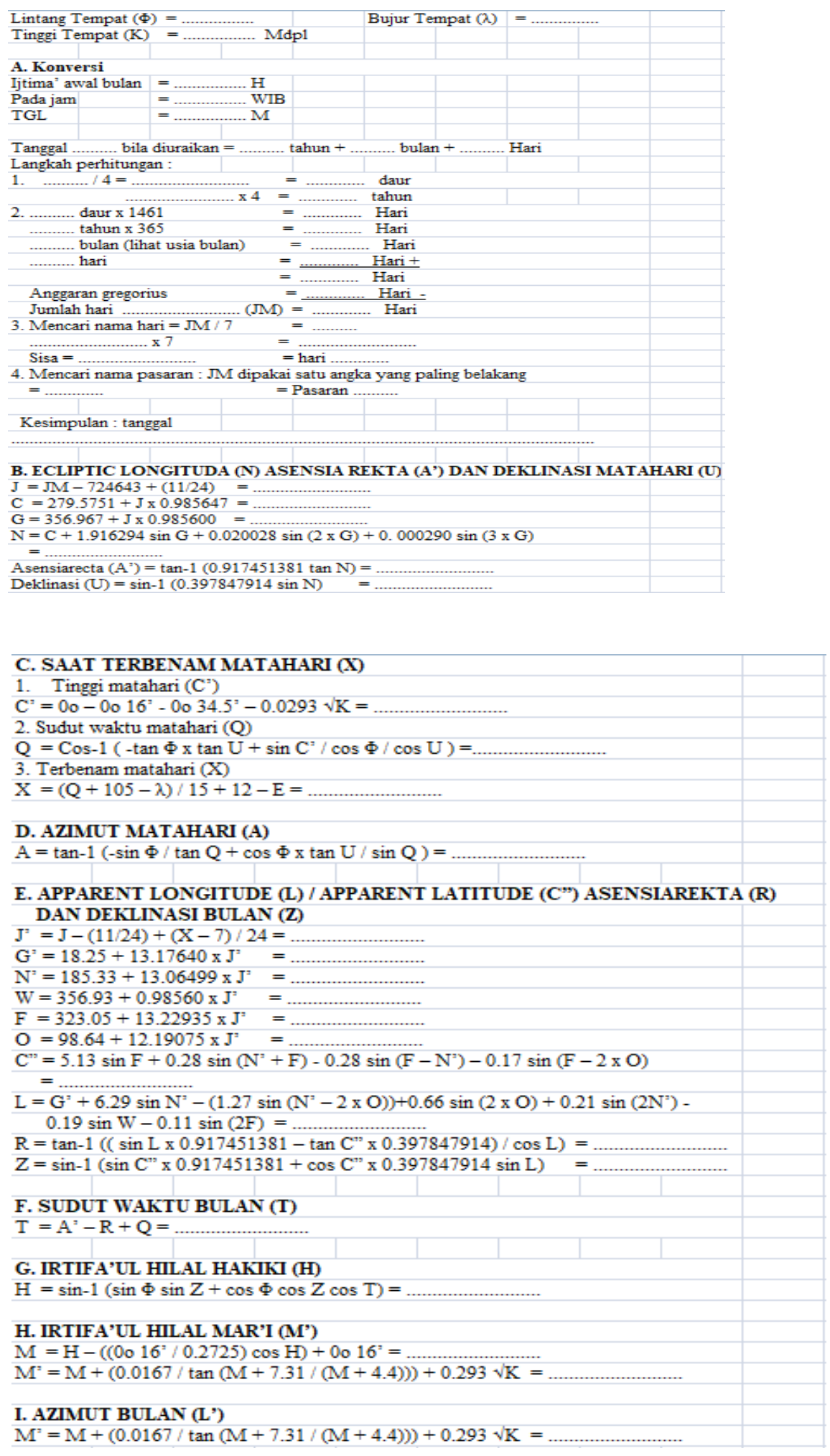


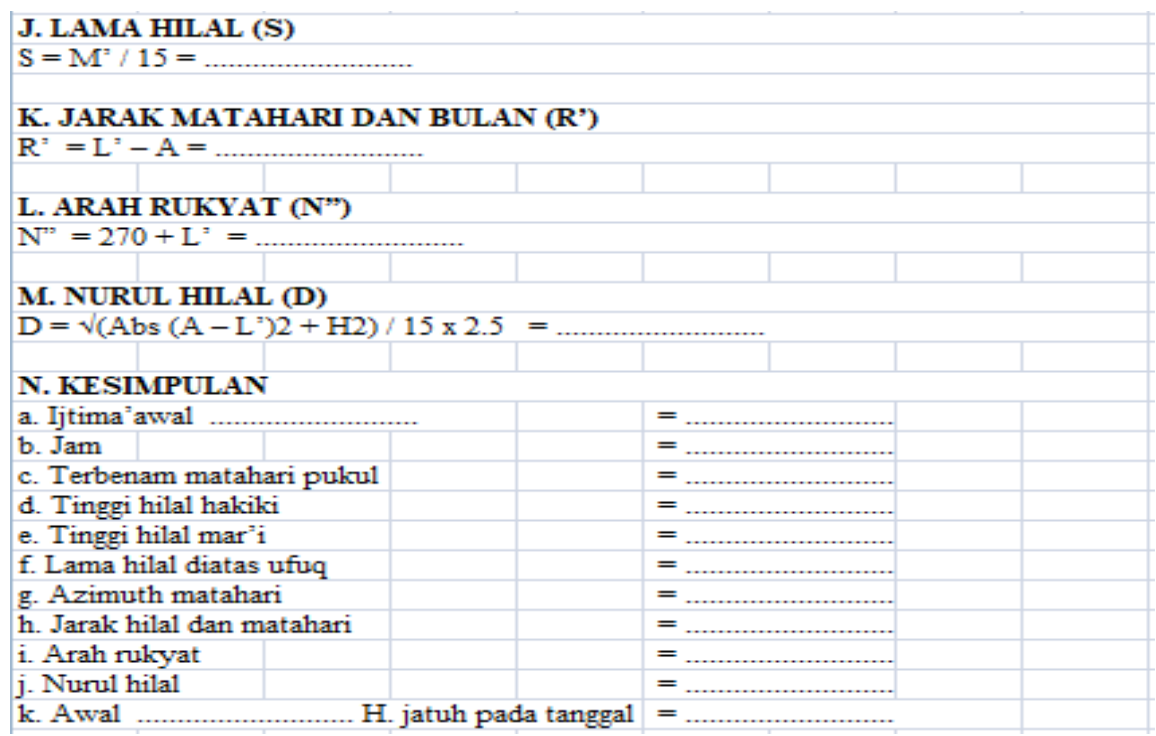

Pada lembaran ini siapa saja yang hendak melakukan perhitungan terkait awal bulan hijriyah terlebih dahulu mencari data lintang tempat $(\Phi)$, bujur tempat $(\lambda)$ dan tinggi tempat $(K)$ dari permukaan laut. Setelah data tersebut dilengkapi barulah dia bisa melakukan perhitungan terkait awal bulan hijriyah. Peneliti beranggapan bahwa metode perhitungan yang seperti ini masih dirasa cukup merepotkan, karena banyaknya rumus perhitungan yang harus di isi hanya untuk mencari awal bulan hijriyah, dan lagi apabila ada kesalahan perhitungan dibagian awal maka bisa dipastikan hasil akhirnya pun akan semakin jauh dari hasil yang semestinya, disini akan cukup merepotkan bilamana harus melakukan perhitungan ulang karena kesalahan seperti itu. Karena alasan itu peneliti memberikan usulan mengenai prototype kalkulator ilmu falak yang mana peneliti harapkan prototype ini nantinya bisa dijadikan sebuah aplikasi yang berguna. 


\section{Analisis dan Rancangan Aplikasi}

\section{Use Case Diagram}

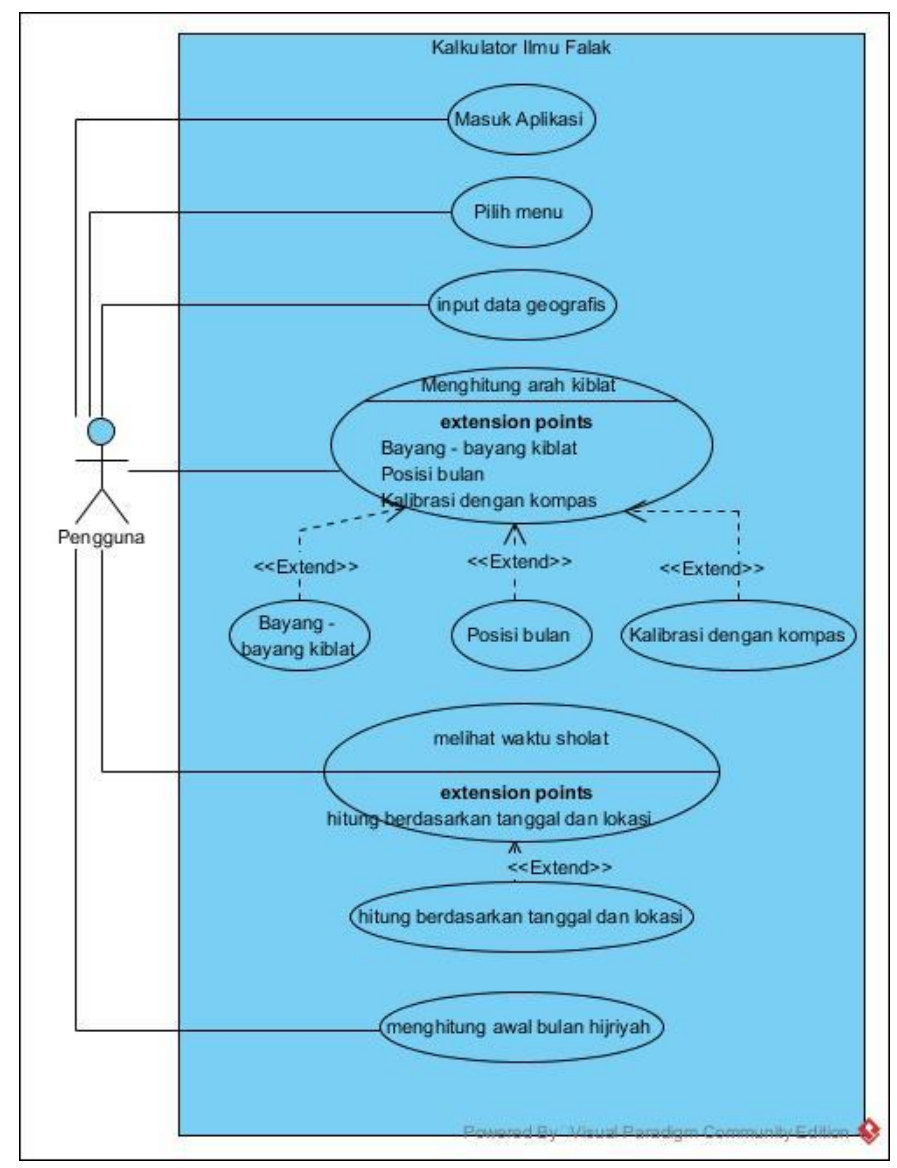

Gambar 1. Use Case Diagram

Use Case Diagram ini memiliki 6 use case utama yang terdiri dari : masuk aplikasi, pilih menu, input data geografis, menghitung arah kiblat, melihat waktu sholat dan menghitung awal bulan hijriyah. Use Case menghitung arah kiblat memiliki tiga buah extension points yang terdiri dari : bayang-bayang kiblat yang berarti pengguna bisa mencari waktu dimana bayangan sebuah benda yang tegak lurus menghadap langsung kearah kiblat, posisi bulan yang berarti pengguna bisa mencari waktu dimana posisi bulan sejajar dengan arah kiblat dan kalibrasi dengan kompas. Use case melihat waktu sholat memiliki satu extension points yaitu hitung berdasarkan lokasi dan tanggal yang berarti pengguna bisa menghitung waktu sholat berdasarkan lokasi dan tanggal yang berbeda. 
Activity Diagram

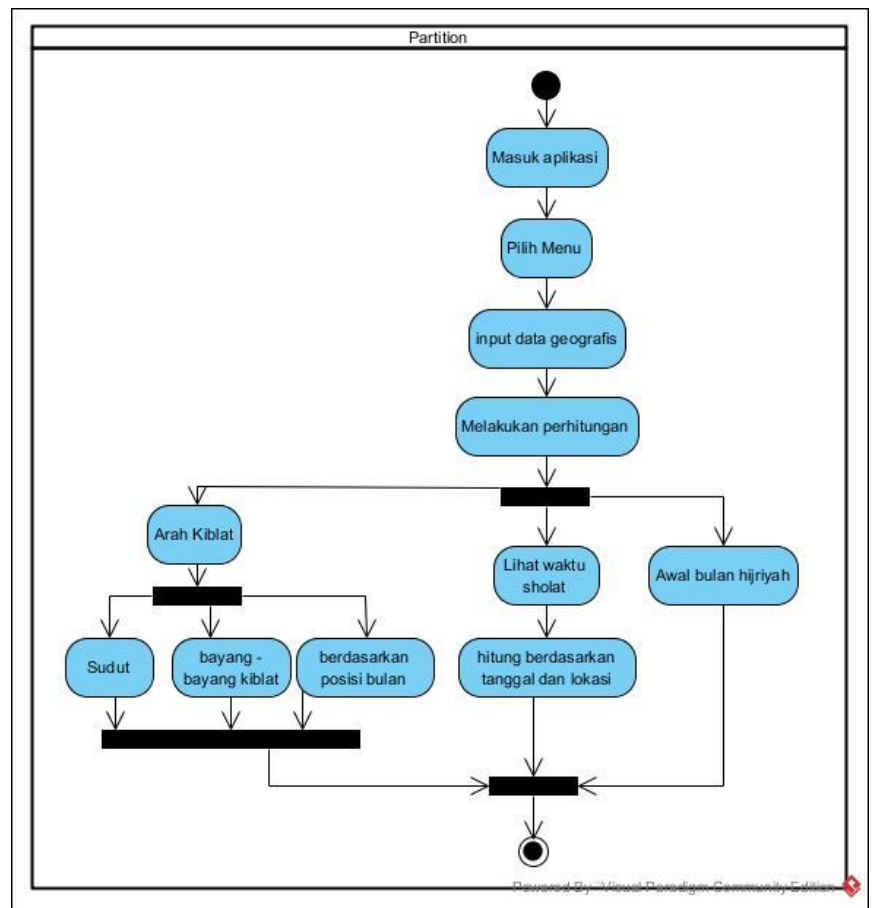

Gambar 2. Activity Diagram

Pada diagram ini pengguna memulai aktivitas dengan cara masuk atau membuka aplikasi, kemudian pengguna bisa memilih menu yang tersedia, lalu jika pengguna ingin melakukan perhitungan maka terlebih dahulu dia harus menginput data geografis yang ada pada menu atur data, setelah itu pengguna bisa melakukan perhitungan yang didalamnya terdiri dari perhitungan arah kiblat, perhitungan waktu sholat dan perhitungan awal bulan hijriyah. perhitungan arah kiblat terbagi menjadi tiga, yaitu menghitung sudut kiblat, menghitung bayang-bayang kiblat dan menghitung arah kiblat berdasarkan posisi bulan. Untuk menghitung waktu sholat, ketika pengguna masuk ke halaman waktu sholat maka aplikasi akan secara otomatis menampilkan waktu sholat berdasarkan tanggal yang sedang berjalan dan kemudian pengguna bisa melakukan perhitungan waktu sholat berdasarkan lokasi dan tanggal yang berbeda.

Sequence Diagram

Sequence Diagram Atur Data

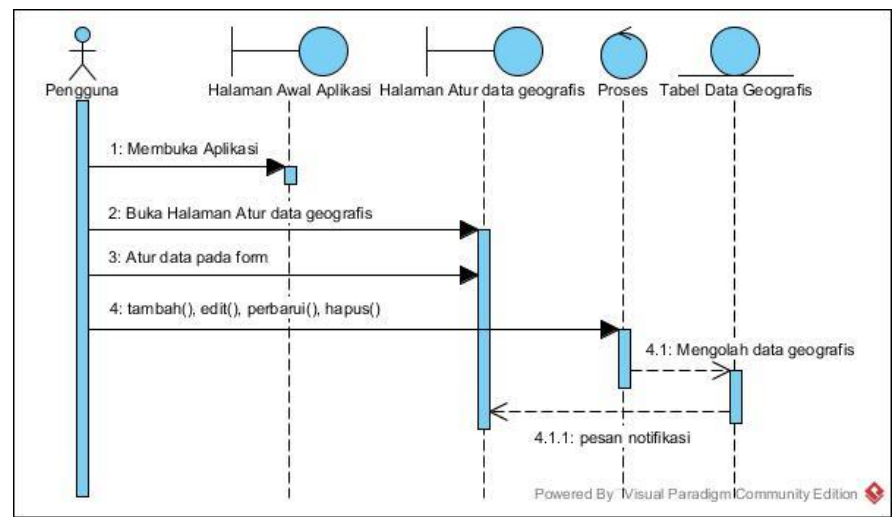

Gambar 3. Sequence Diagram Atur Data 
Pada diagram ini pengguna pertama kali membuka aplikasi yang secara langsung mengarahkan message ke boundary lifeline halaman awal aplikasi, kemudian pengguna membuka halaman atur data geografis dan mengarahkan message ke boundary lifeline atur data geografis, lalu pengguna bisa melakukan proses tambah, edit, perbarui dan hapus data yang kemudian mengarahkan message ke control lifeline proses. Disini control lifeline proses akan melakukan pengolahan data geografis pada tabel dan kemudian mengarahkan reply message ke boundary lifeline halaman atur data geografis.

Sequence Diagram Arah Kiblat

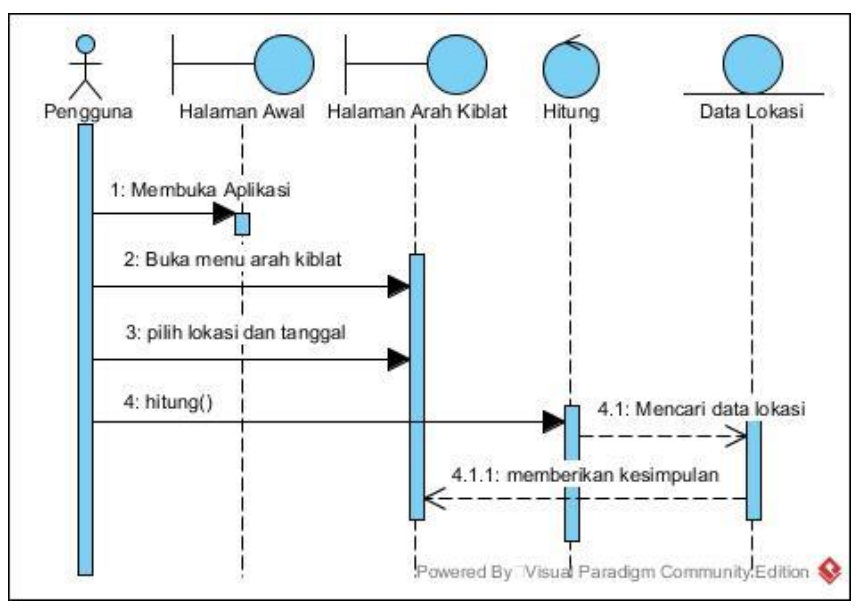

Gambar 4. Sequence Diagram Arah Kiblat

Pada diagram ini pengguna pertama kali membuka aplikasi yang secara langsung mengarahkan message ke boundary lifeline halaman awal aplikasi, kemudian pengguna membuka halaman arah kiblat dan mengarahkan message ke boundary lifeline Halaman arah kiblat, lalu pengguna bisa memilih lokasi dan tanggal yang ada pada halaman arah kiblat, setelah itu pengguna bisa menekan tombol hitung dan message akan diarahkan ke control lifeline Hitung. Disini aplikasi akan memulai mencari data geografis pada tabel berdasarkan lokasi yang telah dipilih untuk kemudian melakukan perhitungan dan memberikan reply message yang berisikan kesimpulan kearah boundary lifeline Halaman arah kiblat.

Sequence Diagram

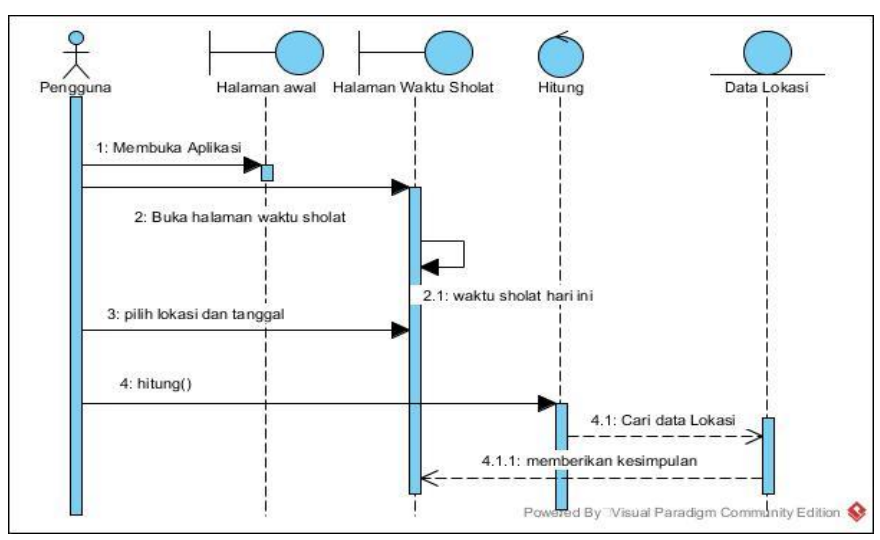

Gambar 5. Sequence Diagram Waktu Sholat 
Pada diagram ini pengguna pertama kali membuka aplikasi yang secara langsung mengarahkan message ke boundary lifeline halaman awal aplikasi, kemudian pengguna membuka halaman arah kiblat dan mengarahkan message ke boundary lifeline Halaman waktu shalat, pada halaman ini aplikasi secara otomatis akan menampilkan jadwal waktu sholat berdasarkan tanggal yang ada pada handphone, kemudian jika pengguna ingin mengetahui jadwal waktu sholat berdasarkan lokasi atau tanggal yang berbeda maka pengguna hanya harus memilih lokasi dan tanggal untuk kemudian menekan tombol hitung dan message akan diarahkan ke control lifeline Hitung. Disini aplikasi akan memulai mencari data geografis pada tabel berdasarkan lokasi yang telah dipilih untuk kemudian melakukan perhitungan dan memberikan reply message yang berisikan kesimpulan kearah boundary lifeline Halaman waktu sholat. .

Sequence Diagram Awal Bulan Hijriyah

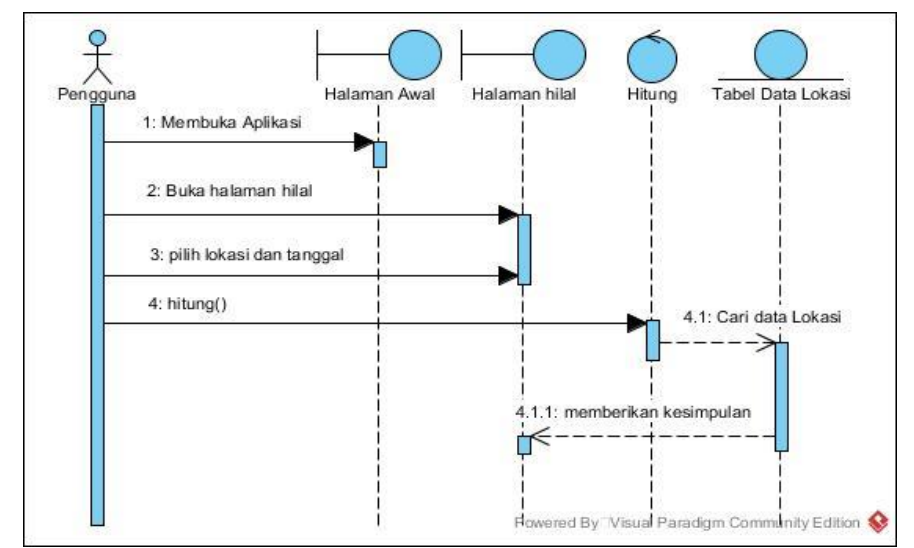

Gambar 6. Sequence Diagram Awal Bulan Hijriyah

Pada diagram ini pengguna pertama kali membuka aplikasi yang secara langsung mengarahkan message ke boundary lifeline halaman awal aplikasi, kemudian pengguna membuka halaman hilal dan mengarahkan message ke boundary lifeline Halaman hilal. Pada halaman ini pengguna bisa memilih lokasi dan tanggal yang mana data tersebut akan dipergunakan untuk memperhitungkan data matahari dan bulan pada awal bulan hijriyah, setelah itu pengguna bisa menekan tombol hitung dan message akan diarahkan ke control lifeline Hitung. Disini aplikasi akan memulai mencari data geografis pada tabel berdasarkan lokasi yang telah dipilih untuk kemudian melakukan perhitungan dan memberikan reply message yang berisikan kesimpulan kearah boundary lifeline Halaman Hilal.

\subsubsection{Class Diagram}

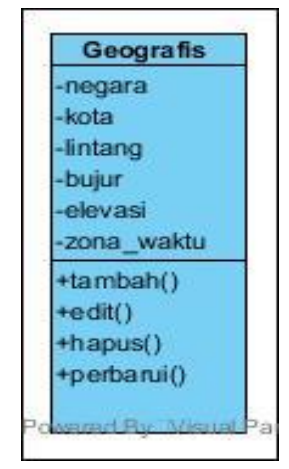

Gambar 7. Class Diagram 
Class diagram untuk aplikasi ini hanya terdiri dari tabel tunggal, berisi atribut yang terdiri dari negara (varchar), kota (varchar), lintang (float), bujur (float), elevasi (float), zona_waktu (integer).

\section{Rancangan Prototype Aplikasi}

\section{Halaman awal aplikasi}

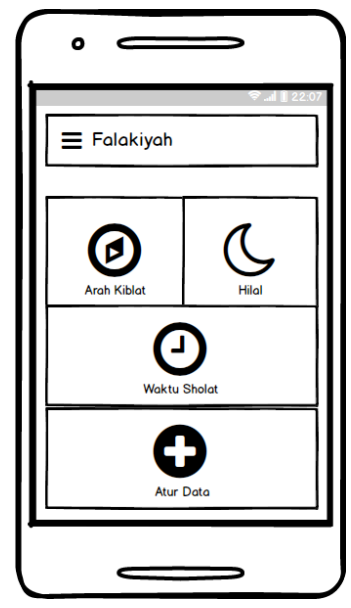

\section{Gambar 8. Halaman awal aplikasi}

Halaman ini merupakan halaman yang akan terbuka ketika pengguna menjalankan aplikasi, disini pengguna bisa memilih menu yang telah disediakan yang terdiri dari :

1. Menu arah kiblat

2. Menu hilal

3. Menu waktu sholat

4. Menu atur data

\section{Halaman atur data}

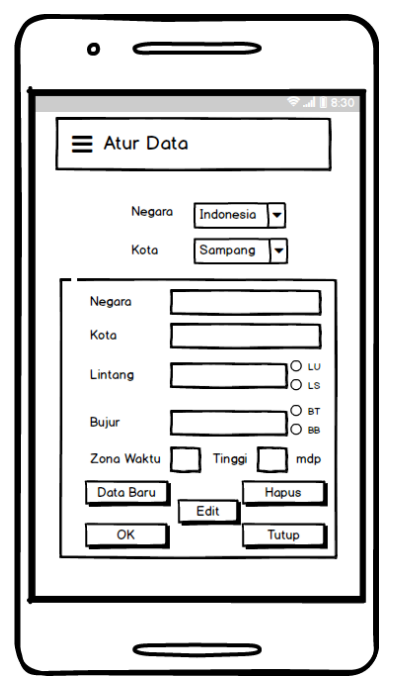

Gambar 9. Halaman atur data 
Halaman ini disediakan untuk mengatur data geografis tempat yang mana pada halaman ini pengguna bisa menambah / mengubah / menghapus data negara, kota, nilai lintang, nilai bujur, zona waktu dan tinggi tempat diatas permukaan laut.

\section{Halaman arah kiblat}

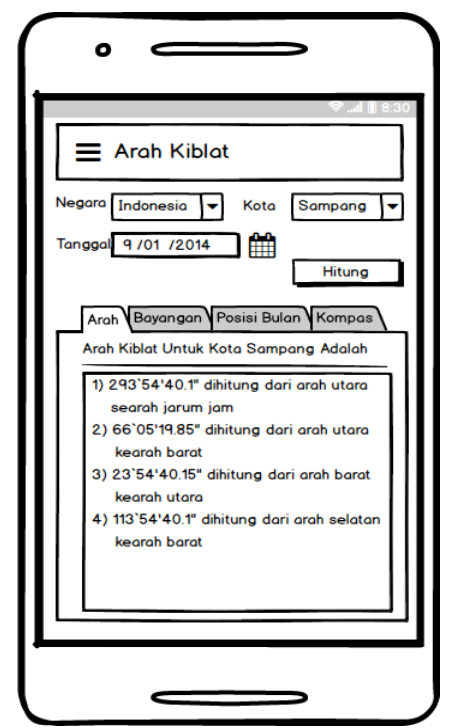

Gambar 10. Halaman arah kiblat

Pada halaman ini pengguna bisa menghitung arah kiblat dengan mudah, dengan cara memilih negara, kota, tanggal dan kemudian menekan tombol hitung. Pada saat pengguna menekan tombol hitung maka aplikasi langsung melakukan perhitungan dan memberikan hasil berupa arah kiblat terhitung dari 4 arah yang berbeda, waktu dimana bayangan sebuah benda ketika menghadap ke arah kiblat, waktu ketika posisi bulan sejajar dengan arah kiblat dan kompas yang arahnya disesuiakan berdasarkan hasil perhitungan.

\section{Halaman Waktu Sholat}

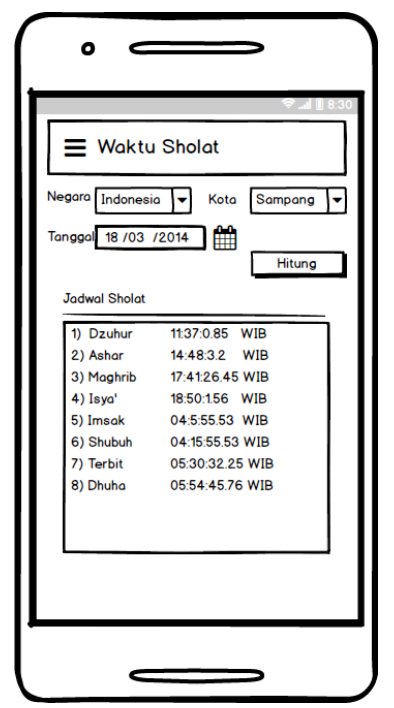

Gambar 10. Halaman waktu sholat

Pada halaman ini jadwal waktu sholat yang ditampilkan secara otomatis disamakan dengan tanggal yang ada pada pengaturan ponsel pengguna, dan jika pengguna ingin menghitung jadwal waktu sholat berdasarkan daerah dan tanggal yang berbeda, maka pengguna hanya harus memilih lokasi dan tanggal untuk kemudian menekan tombol hitung. Disini aplikasi 
akan melakukan perhitungan dan menyesuaikan jadwal sholat yang ditampilkan berdasarkan data lokasi dan data tanggal yang telah dipilih.

\section{Halaman Hilal}

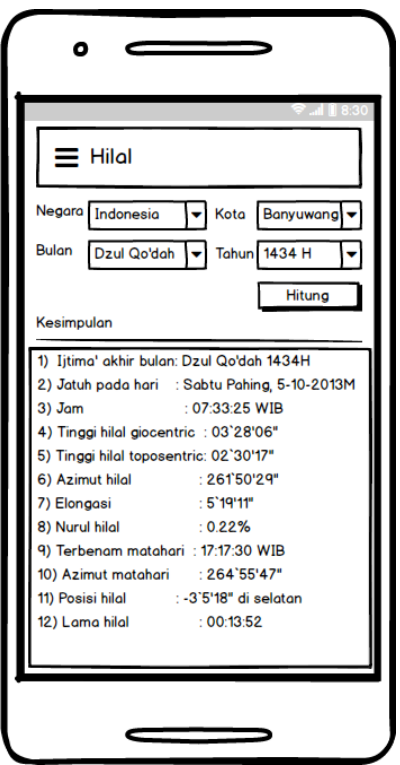

Gambar 11. Halaman hilal

Pada halaman ini pengguna yang hendak melakukan perhitungan dan ingin mengetahui kemungkinan awal bulan hijriyah jatuh pada hari apa, pengguna hanya harus memilih lokasi, awal bulan dan tahun hijriyah yang ingin diketahui. Kemudian pada saat menekan tombol hitung maka aplikasi akan otomatis melakukan perhitungan dan memberikan kesimpulan sebagaimana apa yang ada pada tampilan prototype ini.

\section{KESIMPULAN DAN SARAN}

Kesimpulan yang bisa diambil berdasarkan penelitian yang telah dilakukan yaitu :

1. Aplikasi kalkulator Ilmu Falak dapat memberikan solusi alternatif dalam membantu siapa saja yang ingin mengetahui posisi kiblat, awal bulan Hijriyah, dan waktu sholat, terutama anggota organisasi massa Islam seperti Lajnah Falakiyah dalam melakukan perhitungan sehingga dapat memberikan layanan kepada umat Islam yang membutuhkan. Dengan aplikasi ini, pemakai tidak lagi memerlukan lembar kerja yang banyak dan perhitungan yang panjang.

2. Penggunaan aplikasi kalkulator Ilmu Falak ini juga bisa menghemat waktu dan kertas atau lembar kerja yang dipergunakan untuk melakukan perhitungan. Pemakai aplikasi ini tidak perlu memikirkan bagaimana cara menghitungnya, sehingga risiko akurasi atau ketepatan perhitungan bebas dari human error.

3. Aplikasi kalkulator Ilmu Falak ini memungkinkan pemakai mengetahui kesimpulan hasil perhitungan awal bulan Hijriyah, antara lain informasi tentang:

- Ijtima' awal

- Jam/waktu ijtima'

- Waktu terbenamnya matahari 
- Tinggi hilal hakiki

- Tinggi hilal mar'i

- Muktsul hilal (durasi terlihatnya hilal di atas ufuk)

- Azimuth / arah matahari

- Jarak hilal dan matahari

- Arah ru'ya

- Nurul / besarnya hilal

- Konversi hasil perhitungan Hijriyah ke Masehi

4. Aplikasi ini juga bisa membantu orang-orang yang sedang belajar Ilmu Falak untuk dijadikan rujukan terhadap hasil perhitungan manual dengan menggunakan lembar kerja, sehingga orang-orang yang sedang belajar tersebutmengetahui hasil yang mereka perhitungkan apakah sudah benar atau belum.

Berdasarkan apa yang peneliti usulkan terkait prototype aplikasi kalkulator ilmu falak, maka peneliti memberikan saran kepada siapa saja yang hendak melanjutkan penelitian ini agar :

1. Prototype ini bisa dijadikan aplikasi yang bersifat mobile yang siap pakai, baik yang berbasis Android maupun iOS, yang bisa digunakan oleh siapa saja.

2. Menambahkan metode perhitungan arah kiblat berdasarkan posisi planet Jupiter ataupun berdasarkan posisi planet yang lain.

3. Menambahkan fitur perhitungan gerhana matahari dan gerhana bulan.

\section{DAFTAR PUSTAKA}

[1] Al - Banjary, Nur Hidayatullah, 2013, "Penemu Ilmu Falak”, Yogyakarta: Pustaka Ilmu Yogyakarta.

[2] Darajat, Muhammad Nashiruddin., Abdul Fadlil, Sunardi, 2016, "SISTEM INFORMASI ARAH KIBLAT DAN JADWAL WAKTU SHALAT BERBASIS ANDROID”. Yogyakarta: Jurnal Teknologi, Vol. 9, No. 2.

[3] Raharto, Moedji dan Dede Jaenal Arifin Surya, 2011, "Telaah Penentuan Arah Kiblat dengan Perhitungan Trigonometri Bola dan Bayang-Bayang Gnomon oleh Matahari”, Bandung: Jurnal Fisika Himpunan Fisika Indonesia, vol. 11, No.1.

[4] Aditiani, S. Novira, Dyah Fitriana Masithoh dan Nonoh Siti Aminah, 2015, "PENENTUAN ARAH KIBLAT DENGAN METODE SEGITIGA BOLA", Surakarta: Prosiding Seminar Nasional Fisika dan Pendidikan Fisika (SNFPF), volume 6, No. 1.

[5] Isnaeni, Dede Muhammad., Fitri Mintarsih dan Feri Fahrianto, 2015, "IMPLEMENTASI ALGORITMA MEEUS DALAM PENENTUAN WAKTU SHALAT DAN PENCARIAN MASJID TERDEKAT”. Tangerang: Studia Informatika: Jurnal Sistem Informasi, volume 8, No.1.

[6] Burhan, 2012, "Penetapan Arah Kiblat melalui Media Online : Google Earth dan Qibla Locator”.Kendari: Shautut Tarbiyah, Ed. ke-27 Th. XVIII, November 2012.

[7] Syahruna, Uzal, 2018, “ILMU FALAK METODE AS - SYAHRU”.Blitar: Gunung Tidar Press Lembaga Falakiyah Kabupaten Blitar.

[8] Fathullah, Ahmad Ghazali Muhammad, 2017, “Jami'ul Adillah Ila Ma'rifati Samtil Qiblah”, Sampang: PONPES AL-MUBAROK LANBULAN. 